\title{
The basic concepts essence of the problem of bachelors' professional competence in computer technologies sphere formation
}

\author{
O. P. Sazhiienko \\ Pavlo Tychyna Uman State Pedagogical University, Uman, Cherkassy region, Ukraine, \\ Corresponding author. E-mail: sazhienko@meta.ua
}

Paper received 26.03.18; Accepted for publication 02.04.18.

\section{http://doi.org/10.31174/SEND-PP2018-162VI66-09}

Abstract. In the article on the basis of foreign and native scientific sources analysis, the description and clarification of the essence of the above mentioned problem basic concepts have been made. These are: "competence approach", "competence", "professional competence", "computer technology", "bachelor of Computer Science", "formation of bachelors' professional competence in computer technologies sphere". Professional competence has been interpreted as the readiness and ability of an individual to carry out professional activity on the basis of the acquired knowledge and skills, which contribute to the development of a specialist's creative potential, professional self-development and have systemic features.

Keywords: professional training, competence approach, competence, professional competence, computer technologies, bachelor of Computer Science, formation of bachelors' professional competence in computer technologies sphere.

The problem investigated. One of the dominant features of modern society is undoubtedly the rapid development of computer technology as a priority for any industry. The training of future specialists in computer technologies sphere in the current conditions for the higher education system reformation requires new conceptual approaches that will include updating its content and methodology. To accomplish these tasks, it is important to outline the theoretical foundations for the formation of students' professional competence, in particular, bachelors of Computer Science. First of all, the special scientific attention requires basic concepts characterization of the outlined problem: "competence approach", "competence", "professional competence", "computer technology", "bachelor of Computer Science”, "formation of bachelors' professional competence in computer technologies sphere".

The analysis of recent research and publications. The theoretical background of each of the above mentioned basic concepts is sufficiently presented in scientific sources and is investigated by such scientists:

- "competence approach", "competence": N. Bibik, M. Holovan, O. Zablotska, O. Ovcharuk, O. Pometun, S. Trubacheva and others;

- "professional competence": V. Hrynyova, K. Zaitseva, L. Zubyk, S. Ivanova, V. Koval, N. Nychkalo, T. Otroshko, O. Tsilmakh; S. Martynenko, M. Mykhaskova, Yu. Mosyeko and others;

- "computer technologies": R. Hurevych.

However, there is no consensus on the definitions mentioned above, in particular - in the context of the problem of bachelors' professional competence in computer technologies sphere formation.

The aim of the article is to describe and clarify the essence of the basic problem concepts: "competence approach", "competence", "professional competence", "computer technology", "bachelor of Computer Science", "formation of bachelors' professional competence in computer technologies sphere" on the basis of foreign and native scientific sources analysis.

Main material. From the point of view of the competence approach (N. Bibik, M. Holovan, O. Zablotska, O. Ovcharuk, O. Pometun, S. Trubacheva, etc.), the level of education should be determined by the specialist's ability to solve problems of varying complexity on the basis of available knowledge and experience. Competence approach application to the training bachelors in computer technologies sphere can be a conceptual benchmark in shaping the content of a future specialist's preparation. At the same time, the scientific sources of the aforementioned authors present various interpretations of "competence approach" concept.

The competence approach updating in recent decades is due to a number of factors. First of all, the transition from industrial to postindustrial society is associated with the dynamics of the social processes course, the repeated increase in the information flow, the emergence of new and demarcating professions, since the latter have become more integrated and less special. These changes dictate the need to form a person capable of living in conditions of professional uncertainty: a personality who is creative, responsible, stress-resistant, and able to use constructive and competent actions in different types of life activities. To do this, the orientation of professional education system to the personal qualities development that contribute to a graduate's further professional development is needed.

The analysis of scientific sources (N. Bibik, M. Holovan, O. Zablotska, O. Ovcharuk, O. Pometun, S. Trubacheva, etc.) gives us reasons to assert that in order to overcome the disadvantages of the national higher education the innovative educational projects should be created for a competent specialist's training. Such specialist understands the complicated dynamics of social progress processes. He is able to adequately navigate in various spheres of socio-economic life and self-realization. He can also adequately self-assess and critically understand the potential and ability, take responsibility in professional situations. Such qualities may only be inherent to a competent expert.

In the process of studying world and native experience in implementing the competence approach in modern education, O. Ovcharuk notes that the importance of research in this area is due to "the transition of the world community to the information society, where the priority is considered not to simply accumulate students knowledge and subject skills, but also forming the ability to learn, mastering the information seeking skills, the ability to self-education throughout life, where universal 
values - ecome the determining area of - human professional activity" [9].

N. Bibik provides a competence approach of fundamental importance, since his ideas are reorientated "from the process to the result in the activity measure, the consideration of this result in terms of demand in society, ensuring the ability of the graduate to meet new market demands, have the appropriate potential for practical solutions to life problems, searching for his "I" in a profession and in a social structure" [1].

Consequently, a competent approach in the context of professional training is the focus on the competence formation in the planned professional activities in the process of future specialist's preparation in higher educational establishments. It should be noted that in modern native and foreign pedagogical science there are different characteristics of the concept "competence", which serve as a reflection of the final result of learning and description of various personality traits.

"Competent" in contemporary dictionaries is interpreted as the one "1) who has sufficient knowledge in any sphere; who is well aware of something; clever; based on knowledge; qualified; 2) who has certain powers; full power, full authority" [2, c. 560]. A variety of interpretations of "competence" concept are found in the works of O. Antonova, N. Bibik, S. Vitvytska, O. Dubasenyuk, S. Skvortsova, I. Chemerys and others.

In foreign scientific literature, researchers interpret the "competence" notion as "the quality to be competent; adequacy; possession of the necessary skills, knowledge, qualifications or abilities" [13]. Competence involves "a set of knowledge, skills and attitudes that allow individuals to act effectively or perform certain functions aimed at achieving the relevant standards in professional activities" (L. Shevchuk) [12, c. 9].

Consequently, in the presented interpretations "competence" notion refers to the quality of a person who possesses certain knowledge and abilities, and experience that enables him to act effectively in a particular sphere. For many researchers (N. Bibik, M. Holovan, O. Zablotska, O. Ovcharuk, O. Pometun, S. Trubacheva, etc.) the concept of "competence" outlines a responsible attitude to the case, which guarantees the performer's success in a particular sphere.

In our opinion, it is scientifically appropriate to interpret V. Hrynyova's notion of "competence" as a "personally integrated result of activity", the willingness to act in the sphere of its own competence; individual quality, "which is determined by personal success and diligence in any kind of activity, and contributes to the fulfillment of his duties or competence at a high level" [3]. In the Encyclopedia of Education, the "competence" notion is interpreted as the acquired characteristic of the individual, "which contributes to the young person's successful entry into the modern society life" [1, p. 408], and competence (in the meaning of attribution) as "alienated from the subject, a pre-determined social norm (requirement) for educational preparation..." [1, p. 409]. In the "Great Explanatory Dictionary of Contemporary Ukrainian Language" the "competence" is interpreted as "good knowledge of something; the authority scope of any institution, organization or person" [2, p. 560].

Analysis of the above mentioned scientific and peda- gogical sources made it possible to conclude that in pedagogical science there are two methodological approaches to understanding the essence of the term "competence", presented by us schematically (Picture 1) and named by us as:

a) holistic, in which competence is an integral part of "life competence" general concept (M. Holovan, V. Hrynyova, A. Kyselytsa, O. Ovcharuk, L. Shevchuk, etc.);

b) systematic in which "competence" notions are not identical, but they constitute the general competence approach problem area (N. Bibik, S. Vytvytska, O. Dubasenyuk, O. Zablotska, O. Pometun, S. Skvortsova, S. Trubacheva, etc.):

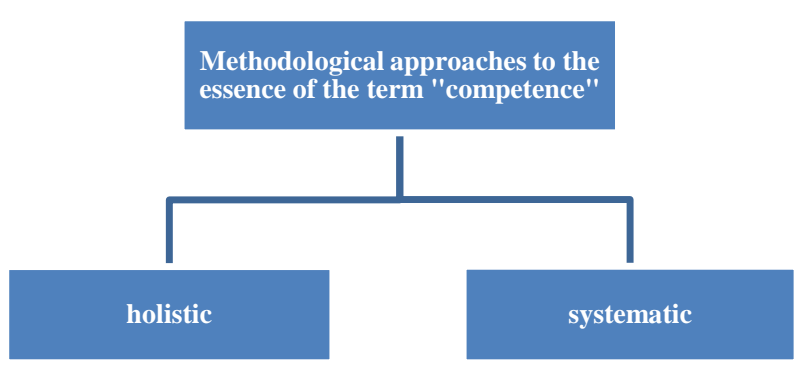

Picture 1. Methodological approaches to the essence of the term "competence" in the context of professional education

In practice, scholars have common views on the fact that competence is an individual's ability to act in a particular situation based on the knowledge and skills available to him, his attitudes and value orientations, and his experience. Competence (in the meaning of attribution) is a sphere / field of knowledge in which a person shows his competence or incompetence in a particular situation for the purpose of carrying out an effective activity, performing the task or solving the problem and obtaining the optimal result.

Thus, we consider competence as a personal dynamic combination of knowledge, skills, experience, professional-ideological qualities, moral and ethical values, which determines the ability of a person to successfully implement in a certain type of activity and is the result of training at a certain level of higher education. Competences are individual integrated knowledge and skills that form the essence of competence, determining the range of issues that characterize this quality.

For our study, professional/specialty competence is relevant, and therefore, we will describe them in detail.

Concerning the coherence of "professional competence" and "specialty competence" concepts, it is appropriate to first analyze "professional" and "specialty" definitions. From the philological point of view, these concepts, according to the modern explanatory dictionary, are identical, since specialty is synonymous with the word "profession" [2, c. 1530].

Despite the philological certainty of the analyzed concepts, in scientific sources, the comparative characteristics of "professional competence" and "specialty competence" definitions prevail, avoiding the use of only one of the concepts:

- "professional competence" prevail (V. Hrynyova, K. Zaitseva, L. Zubyk, S. Ivanova, V. Koval, N. Nychkalo, T. Otroshko, O. Tsilmah and others); 


\section{- "specialty competence" (S. Martynenko, M. Mykhaskova, Yu. Moseiko and others).}

Occasionally in the scientific sources (for example, in the works of S. Martynenko [6], S. Skvortsova [10]) there is a complete identification of these concepts with the use of both terms due to the oblique or in parentheses: "professional / specialty competence"; "professional (specialty) competence". At the same time, O. Tymets $[11$, p. 16] considers professional competence as a component of "professional competence" concept. In the future, in our study, we will treat these concepts as synonyms, according to the formulated research topic, the preference for "professional competence" concept without changing the definition in direct quotations.

We will analyze examples of "professional competence" concept interpretation (precisely in such a phrase):

- the integral personality quality, manifested in its general ability and readiness for a certain type of professional activity, and "is based on a holistic set of knowledge, skills and experience gained in the process of learning and socialization and focused on independent and successful participation in professional activity" (Y. Moseiko) [8, c. 18];

As you can see, the author chooses two dominant positions - "ability" and "readiness". This approach allows characterizing the professional competence in a holistic way - in the interdependence of professionally acquired capabilities of the future specialist's personality and his professional self-realization.

- the quality reflection of future specialist's professional development, which "reveals the internal attitude peculiarities to the chosen profession and characterizes the updating and enrichment of the worker's "I-concept" in terms of self-awareness as a qualified specialist" (S. Martynenko) [6];

In this interpretation, we follow the psychological approach to understanding the essence of professional competence as a component of the specialist's personality structure with an emphasis on the activity component.

- the ability to certain professional activities on the basis of special knowledge and skills, experience of emotional and value attitude to professional activity "in accordance with social requirements and values" (M. Mykhaskova) [7];

The author chose "ability" based on activity and social approaches as the dominant term in professional competence interpretation.

- "one of professional competence components is a multidimensional, integral education, which ensures personal formation effectiveness (presence of professional activity motivation and student's value attitude to studying) and professional activity mastering, which is associated with the ability to intelligently master the complex of activity knowledge and methods on a particular subject... and conduct research on selected topics ..., as well as develops ... thinking, testifies to the desire for a constant professional and personal development" (O. Timets) [11, c. 16]; "it is the result of mastering a set of competencies" (O. Timets) [111, c. 30].

Thus, the researcher outlines professional competence in terms of an integrated approach, defining specialist's desire and ability to a certain type of activity as key components of this concept.
According to the analysis results of the above mentioned and other scientific sources, researchers put two positions of "professional competence" concept based on its interpretation:

- integrative approach ("readiness") is an integrative, complex personality trait (V. Koval, V. Lozovetska, L. Kryvtsova, Yu. Moseiko, N. Nychkalo, O. Nikulochkina, T. Otroshko, O. Timets, etc.);

- activity approach ("ability") is the ability to a certain type of activity (V. Hrynyova, K. Zaitseva, L. Zubyk, S. Ivanova, S. Martynenko, M. Mykhaskova, S. Skvortsova, O. Tsilmakh, etc.).

We will clarify the definitions of "readiness" and "ability", based on the vocabulary interpretation. In the classic interpretation "readiness" is "the desire to do something" [2, c. 257], and "ability" is the facility to "carry out, perform, do something, behave in a certain way" [2, c. 453].

Thus, the core of "readiness" is desire, and "ability" is facility. Combining the above-mentioned methodological approaches to understanding these concepts, we present the essence of professional competence schematically (Picure 2):
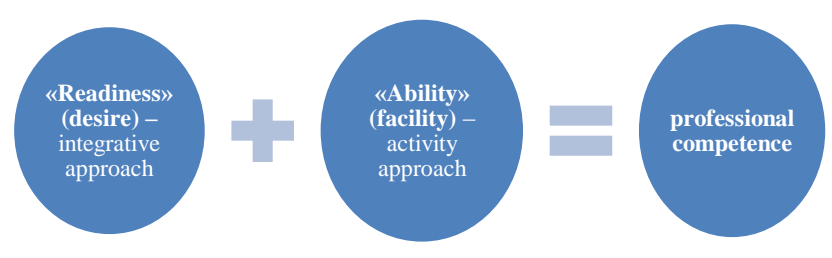

Picture 2. The essence of future specialists' professional competence

We believe that the meaning of "professional competence" should be interpreted as follows: readiness and ability of the person to carry out professional activity on the basis of the acquired knowledge, skills, experience, which promote the development of specialist's creative potential, professional self-development and have systemic features. Person's professional competence under certain conditions develops in a long-term activity process.

An important category of our work is the term "formation", which in the reference literature is interpreted as "the effect of the verb "to form" meaning as to give something a form, shape; organize, compile, create" [2, c. 1544].

In the context of our study, we consider V. Kremen's opinion that professional competencies formation is a purposeful and organized process for the acquisition of future specialists' professional experience, which is carried out through the education content, which encompasses not only the list of educational subjects, although it is their means that combines the content necessary for assimilation, with the means of its assimilation, but also the professional skills and abilities that are formed in the process of subject studying [5].

Thus, in our opinion, "the formation of professional competence" is purposeful process of future specialists' mastering a set of knowledge and skills, contributing to the development of their creative potential, professional self-development. The final result of forming the future specialist's professional competence is the developed level of readiness and person's ability to carry out profes- 
sional activity on the basis of the indicated factors and qualities.

Professional competence essence and content are determined by the sphere / field of activity. Consequently, the terminological consistency in the plane of our study is needed for the terms "sphere" and "field". Thus, in the reference literature the term "sphere" is "a branch of knowledge, production" [2, c. 1419]; "field" is a certain area of science [2, c. 219]. Thus, these definitions are synonymous: they can be used to avoid tautology. Taking into account the research topic wording, in the future we will give priority to the notion "sphere" in the phrase "bachelors of computer technologies sphere". At the same time, in the scientific sources tangent to our problem synonymously with the concepts of "sphere" and "industry" partly the concept "area" is used. We should note that, according to the interpretation, the term "area" has a mathematical and administrative-geographical meaning [2, c. 807], therefore it cannot a synonym to the above mentioned concepts.

As for the bachelors' professional competence formation in computer technologies sphere, first of all, we should state, that computer technologies (information technologies - IT) is a general name of technology using computers. The Encyclopedia of Education provides an interpretation of the broader concept - "Information and Telecommunication Technologies in Education (ITTE)". These are "technologies that use special technical information tools (computers, audio, cinema, video, etc.) ... the computer technology, which is based on the use of a certain formalized model of content presented by educational software written in the computer memory, and having the capabilities of telecommunication networks" (R. Hurevych) [4, c. 364]. Instead, the notions interpretation of "information and communication learning technologies" and "computer technologies" in the Encyclopedia of Education [4] is not presented. In view of the sufficient research in the last decades of the term "technology", we will not go into its thorough analysis.

R. Hurevych stresses that future educators' readiness to apply the ITTE "should be seen as a teacher's professional and personal quality" [4, c. 365].

Due to the rapid development of computer technology, knowledge in this area is rapidly aging. Therefore, when preparing specialists of the modern information space, it is necessary that knowledge has a creative and exploratory nature, since such training stimulates cognitive activity development, promotes creative and mental abilities development. Computer education now should be considered as a criterion for a future specialist's general professional training. He must have the basic concepts and terminology on computer science, understand the computer system structure and principles, use operating systems, improve practical skills of software use.

Currently, the educational process in higher educational establishments in the specialty 015 Professional education (Computer technologies) of the bachelor's educational degree is carried out in accordance with the Standard of Basic Higher Education, in particular - in pedagogical universities. The purpose of the Education Program [9] for such training is to provide knowledge in the professional education computer technology sphere with broad access to employment; students' preparation who have found a particular interest in certain areas of computer technology for further study during the learning process. Such further education, above all, is master's programs in the professional computer technologies education. This is an opportunity to study according to the program of the second cycle of knowledge, which is consistent with the obtained bachelor's degree, or adjacent one.

According to the educational program of this specialty, we should note that Bachelor of Computer Science, in general, is a specialist, ready to apply his knowledge in almost all spheres of industrial and non-productive activity, where computer technologies are used. This is a specialist who has successfully completed the curriculum of the first level of higher education in the amount of 240 ECTS credits, fluent in computer technology, and received a bachelor's degree - a diploma of one degree, confirming the formation of his professional competencies sufficient to fulfill the duties of the corresponding level. Currently, bachelor of IT qualifies as "a specialist in computer technology sphere, teacher of practical training in computer technology" [10].

Consequently, the formation of bachelor's professional competence in computer technologies sphere is considered by us as a systematic, purposeful and organized process of training a specialist, capable of working in various fields of professional modern computer technology and Internet; use methods of making scientifically based solutions with the help of expert systems and new information technologies, etc.

The urgent need is to generalize the existing theoretical and practical experience in preparing future bachelors of Computer Science and to modernize the theoretical and methodological provisions of their training on a competence basis by strengthening the practical education orientation provided in case its fundamentality is preserved.

Conclusion. Thus, on the basis of foreign and native scientific sources analysis, the description and clarification of the essence of the above mentioned problem basic concepts have been made. These are: "competence approach", "competence", "professional competence", "computer technology", "bachelor of Computer Science", "formation of bachelors' professional competence in computer technologies sphere".

It is substantiated that the organization of bachelors' professional preparation process in computer technologies sphere in a higher educational establishment is a means of formation and subsequent development of their respective competencies. Bachelors' professional preparation in computer technologies sphere is a compulsory component of higher education, the content of which are professional disciplines, based on a competence approach. The final result of bachelors' professional competence in computer technologies sphere formation has been defined by the developed level of an individual's readiness and ability to carry out professional activity on the basis of the stated indicators and qualities in this sphere, first of all - the ability to work in various professional fields of modern computer technology and Internet; to use methods of making scientifically based solutions with the help of expert systems and the latest information technologies, etc.

At the same time, as shown by the scientific material analysis presented in the article, the prospect of further 
research is to identify the components of the integrative concept of "bachelor's professional competence in com- puter technologies sphere".

\section{REFERENCES}

1. Bibik N. M. Kompetentnist u navchanni. Entsyklopediia osvity. Akad. ped. nauk Ukrainy; holov. red. V. H. Kremen. K.: Yurinkom Inter, 2008.

2. Velykyi tlumachnyi slovnyk suchasnoi ukrainskoi movy. Uklad. i holov. red. V. T. Busel. Irpin: VTF «Perun», 2004.

3. Hrynova V. M. Pro spivvidnoshennia poniat «profesionalizm», «profesiina kultura», «profesiina kompetentnist», «profesiina pidhotovka». Pedahohika ta psykholohiia. Vyp. 45. 2014.

4 Hurevych R. S. Informatsiino-telekomunikatsiini tekhnolohii v osviti (ITKT). Entsyklopediia osvity. Akad. ped. nauk Ukrainy; holov. red. V. H. Kremen. K.: Yurinkom Inter, 2008.

5. Kremen' V. H., Mazorenko D. I., Zavietnyi S. O. Filosofiia spilkuvannia : monohrafiia. Kharkiv : KhNTUSH im. P. Vasylenka, 2011.Martynenko S. A. Fakhova kompetentnist: psykholoho-pedahohichnyi aspekt [Elektronnyi resurs]. URL: https://www.narodnaosvita.kiev.ua/?page_id=527

6. Mykhaskova M. A. Formuvannia fakhovoi kompetentnosti maibutnoho vchytelia muzyky: avtoref. dys. ... kand. ped. nauk. Kyiv, 2007.

7. Moseiko Y. V. Formuvannia fakhovoi kompetentnosti maibutnikh inzheneriv-metalurhiv u protsesi vyvchennia profesiino oriientovanykh dystsyplin : avtoref. dys. ... dok. ped. nauk. Zaporizhzhia, 2010.

8. Ovcharuk O. V. Rozvytok kompetentnisnoho pidkhodu: stratehichni oriientyry mizhnarodnoi spilnoty // Kompetentnisnyi pidkhid u suchasnii osviti: svitovyi dosvid ta ukrainski perspektyvy. Kyiv, 2004.

9. Osvitnia prohrama. Profesiina osvita (Kompiuterni tekhnolohii). Osvitnii stupin: bakalavr za spetsialnistiu 015 Profesiina osvita (Kompiuterni tekhnolohii). Uman, 2016.

10. Skvortsova S. Profesiina kompetentnist vchytelia: zmist poniattia. Formuvannia profesiinoi kompetentnosti maibutnoho vchytelia pochatkovoi shkoly v umovakh VNZ: Materialy vseukrainskoi naukovo-praktychnoi konferentsii (Uman, 8-9 zhovtnia 2009 r.). Uman: PP Zhovtyi, 2009.

11. Timets O. V. Teoriia i praktyka formuvannia fakhovoi kompetentnosti maibutnoho vchytelia heohrafii u protsesi profesiinoi pidhotovky: avtoref. dys. ... dok. ped. nauk. Cherkasy, 2011.

12. Shevchuk L. O. Formuvannia informatsiinoi kompetentnosti maibutnikh uchyteliv u vyshchykh navchalnykh zakladakh Respubliky Polshcha: avtoref. dys... kand. ped. nauk. Uman, 2011.

13. Dictionary.com [Electronic resource]/ URL: http://dictionary.reference.com/browse/competence.].

Сущность базовых понятий проблемы формирования профессиональной компетентности бакалавров сферы компьютерных технологий

\section{А. П. Сажиенко}

Аннотация. В статье на основе анализа зарубежных и отечественных научных источников осуществлено характеристику и уточнено сущность базовых понятий обозначенной проблемы: «компетентностный подход», «компетентность», «компетенция», «профессиональная компетентность», «компьютерные технологии», «бакалавр компьютерных технологий», «формирование профессиональной компетентности бакалавров сферы компьютерных технологий». Профессиональную компетентность истолковано как готовность и способность личности осуществлять профессиональную деятельность на основе приобретенных знаний, умений, навыков, опыта, способствующих развитию креативного потенциала специалиста, профессиональному саморазвитию.

Ключевые слова: профессиональная подготовка, компетентностный подход, компетентность, компетенция, профессиональная компетентность, компьютерные технологии, бакалавр компьютерных технологий, формирование профессиональной компетентности бакалавров сферы компьютерных технологий. 